\title{
RELATEDNESS BETWEEN K13 ENGLISH CURRICULUM AND WRITING MATERIALS IN BAHASA INGGRIS TEXTBOOK
}

\author{
Wirda Yanti ${ }^{1}$, Alisa Franstia Maria Silaban ${ }^{2}$, Erikson Saragih $^{3}$ \\ ${ }^{123}$ English Education Department, University Prima Indonesia, Sumatera Utara, Indonesia \\ wirdayanti426@gmail.com
}

\begin{abstract}
Textbook is an important media because contains learning materials that employed learners to get knowledge through learning process. To support the learning process, the textbook should be appropriate to the 2013 curriculum. This research used content analysis. The objectives of this research are (1) to explain the topics of writing materials in Bahasa Inggris textbook (2) to explain the writing materials written in Bahasa Inggris textbook (3) to explain the relatedness between writing materials and the K13 curriculum. Here, the result of this research shows that (1) The topic of writing material is appropriate to the 2013 curriculum. (2) The form of writing tasks meet as good criteria because the textbook gave good guideline and explanation exactly in social function, text structure and language feature. (3) The writing material in Bahasa Inggris textbook is related to the English 2013 curriculum because the writing material in the textbook have implemented based on the content of the syllabus of the 2013 curriculum. This textbook is good to use because it is suitable for students in Senior High School for the twelfth grade to increase their writing skills.
\end{abstract}

Keywords : Content analysis, writing material, 2013 curriculum 


\section{CHAPTER I INTRODUCTION}

As part of education system, textbook is a media as the main source of learning for students to increase their knowledge through the activity of teaching and learning. According to Graves (2000), the textbook is a book that used as a standard material for students in both formal and non formal studies and as a tool for teaching and learning in the classroom. Furthermore, According to (Van Dormolen, 1986), textbook consist two important pedagogic functions: a curricular aspect, which aims deployed students to understand the subjects that will be taught, and a conceptual aspect, is important part to develop the students' cognitive.

There are many English textbooks, English textbooks should be based on the English curriculum. A good textbook must be appropriate and relevant to the curriculum and can support curriculum implementation in the program of teaching and learning. (Sholichatun, 2011) mentioned that curriculum is importance part of education program that have goals and outcomes, learning arrangement, evaluation, and documentation that related to developing the quality of the students' education. As we know that the curriculum of 2013 (K13) is an education system prevailing in Indonesia which is applied by the government as a fixed curriculum. Besides (Mulyasa, 2013), stated that as part of the 2013 curriculum that is mplemented in Indonesa, textbook play an important one to determine the success of the educational system.

There is a book entitled Bahasa Inggris textbook in Indonesia which Kementrian Pendidikan dan Kebudayaan Republik Indonesia published the textbook on 2018 revised edition for students senior high school as learning English source generally. The textbook presented based on 2013 curriculum which is structured to improve students' language skills, namely speaking, listening, reading and writing. We know that writing is difficult to learn than those skills. Most students are difficult to express their ideas or opinions on a piece of paper. It because when writing they have to master enough vocabulary, spelling and grammar. Langan (2001, p. 1) stated writing is an activity in the form of pouring ideas into the continued process. It means that writing requires a series of steps to think creatively and the goal is giving information, idea and opinion to the reader. 
The function of the 2013 currculum that applied in Indonesia is to emphasize the importance of attitudes, knowledge and skills, the material in the textbook used a text-based learning approach by placing English as a vehicle for communicaton both orally and written, and the book aims to improve the students' competence of knowledge about the type, rules, context of a text and the competence of skills are presenting in a written and oral text.

In supporting the students' writing skills, all writing materials in the textbook should conform with the standard criteria and basic competencies, indicators and learning objectives that should be achieved in the textbook. According to Tomlinson (1998, p. 2), materials can be defined as anything such as visual, auditory, kinesthetic and linguistics which can help the teacher and student in the activities of teaching and learning. Besides, Hutchinson and Waters (1987, p. 107) mentioned that good material can motivate students to learned more and enjoyed the subject matter because it involved them thinking creatively and give them opportunities to use their knowledge and skills.

Regarding to the explanation above, the researcher interest to conduct a research entitled "Relatedness between English K13 curriculum and writing material in Bahasa Inggris textbook" which focuses on analyzing of writing material covered in the textbook. The reason why the researchers choose the textbook is because the textbook is based on the 2013 curriculum which the 2013 curriculum plays an important thing to determines student success in the scope of learning. Besides, the activities of the writing materials offered in the textbook are not comprehensible enough, the exercises are not presented explicitly, so students difficult to write. From those difficulties are found, the teacher should explain and develop the writing material to make the students are more understand and able to express their ideas and opinions with the correct grammar and sentence structured. Therefore through the analysis, the researchers can give specific information in detail on whether the writing material in the textbook is related or not to the English 2013 curriculum and meet the criteria as a good textbook that can used for learner in the teaching and learning process.

\section{The Problems Of Study}

The problems of the study on the background above are stated as the followings:

1. What topics are offered in writing material sections in the Bahasa Inggris textbook?

2. How are writing materials written in Bahasa Inggris textbook? 
3. How is the relatedness between writing materials and K13 curriculum?

\section{The Objectives of the Study}

The objectives of the study on the problems above are stated as the followings:

1. Describing the topics of writing materials in Bahasa Inggris textbook.

2. Describing writing materials written in Bahasa Inggris textbook

3. Describing the relatedness between writing materials and K13 curriculum. 


\section{CHAPTER II \\ RESEARCH METHOD}

\section{The Research Design}

Regarding to this research, The researchers used a qualitative research approach with a descriptive method. The descriptive method aims to see the phenomenon of the subject that will be investigated such as behavior, perception, motivation, action and others (Sugiyono, 2010). Besides, Anderson (2007) mentioned that a descriptive presentation of qualitative data as content analysis. The Content analysis is needed because the researchers would analyze the content of Bahasa Inggris textbook, especially the writing material offered in the textbook. The Content analysis is needed because the researchers would analyze the content of Bahasa Inggris textbook, especially the writing material offered in the textbook. According to Stemler (2001), content analysis can be defined as a technique, which is used to compress many words of the text objectively based on the systematic rules of coding.

Based on the theory mentioned above the researchers would like to present the topic of writing materials in Bahasa Inggris textbook, the writing materials written in Bahasa Inggris textbook and the relatedness between writing materials in the textbook and K13 curriculum.

\section{The Object Research}

The writing material covered in Bahasa Inggris textbook is the object of this research, which the textbook published by 'Kementrian Pendidikan dan Kebudayaan Republik Indonesia' in the 2018 revised edition. Bahasa Inggris textbook consists of 176 pages and 11 chapters. Authors by Utami Widiati, Zuliati Rohmah, and Furaidah. The textbook presents based on the 2013 curriculum which is used for the twelfth grade of senior high school.

\section{The Research Instruments}

In collecting the data, the researchers used content analysis as the instrument since it deals to analyze the writing material covered in Bahasa Inggris textbook. All data obtained will 
describe from the documentation. The data of documentation was taken from observing the textbook and the English syllabus of the 2013 curriculumm for the twelfth grade senior high school.

\section{The Technique of Collecting Data}

In terms of collecting the data, the researchers used a documentation study. According to Rully Indrawan and Poppy (2014, hal. 139), the documentation study aims to help understand a phenomenon in terms get information through the data analysis.

Here, the researchers do some action in collecting the data:

\section{Reading}

The researchers were reading Bahasa Inggris textbook focus on finding the writing material written in every chapters of the textbook.

2. Identifying

After reading the textbook, the researcher identified the writing material covered in Bahasa Inggris textbook based on the English syllabus of the 2013 curriculum.

\section{The Technique of Analyzing Data}

In terms of analyzing the data, the researchers employing content analysis which was used for qualitative research. Content analysis is used as the technique of reporting the data written.

There are some procedures that the researchers took in analyzing data, they are :

1. Selecting

The researchers read the Bahasa Inggris textbook to select which writing material would be discussed as the writing material covered in every chapters of the textbook.

\section{Categorizing}

The researchers categorizing the writing material that has been selected in Bahasa Inggris textbook with some aspect. Some aspects of writing material that the researchers will be used to analyze the data.

3. Analyzing 
After categorizing, the researchers analyzing the writing materials are found in the textbook based on the English syllabus of the 2013 curriculum.

4. Inferring

The researchers conclude the finding of the analysis in a brief description. 


\section{CHAPTER III \\ RESULTS AND DISCUSSION}

\section{Results}

\section{The topics are offered in writing material sections in the Bahasa Inggris textbook}

The researchers analyzed Bahasa Inggris textbook which published by Kemendikbud 2018 revised edition for the twelfth grade of student Senior High School. The textbook consists of 11 chapters and 176 pages. Every chapters contain writing material. The researchers found all topics of writing material are offered in the textbook, they are in Chapter 1 is (May I Help You). Chapter 2 is (Why Don't You Visit Seattle). Chapter 3 is (Creating Captions). Chapter 4 is (Do You Know How to Apply for a Job?). Chapter 5 is (Who was Involved?). Chapter 6 is (Online School registration ). Chapter 7 is (It's Garbage In, Art Works Out?). Chapter 8 (How to Make). Chapter 9 is (Do it carefully!). Chapter 10 is (How to Use Photoshop), and Chapter 11 is (Let's Make a Better World for All).

Chapter 1 (May I Help you)

Task 1, page 12. Group work. Work in groups of 4. Write a dialog for each of the following situations. You are doing the History Project with your group at the library after school. Your best friend cannot finish his/her part. Offer a help to do it together.

\section{The writing materials are written in Bahasa Inggris textbook}

The writing task above is ordered the students to write sentences dealing with grammar, which they work in groups to write dialogue for offering help. The activity involved the students using such as what can I do...? and what if...?

The writing task above is ordered the students to write sentences dealing with grammar.

Chapter 2 (Why Don't You Visit Seattle)

Task 1, page 27. Work in groups of 3-5 students. Find other text that uses "if clause" in it. Then identify the "if clause" in your text together with your group. Find the patterns as well. Write the result in the following spaces.

Chapter 3 (Creating Captions)

Task 1, page 39. What's the caption? Look at the following pitcure and write a caption for the pitcure. 
The activity ordered them to work in groups to find the text using the if-clause and the patterns of the if clause itself.

The writing task above is ordered the students to write sentences dealing with grammar, which they ordered to give a caption according to the picture above. The activity involved them writing using appropriate words, phrases, clauses, and sentences.

Chapter 4 (Do You Know How to Apply for a Job?)

Task 2, page 59. Let's apply for a job. Write an application letter to respond to the above job vacancy. Use these points about parts of application letters to help you.

1. Write your address.

2. Write the address of the company your application letter is sent to.

3. Write down the name of the person in charge.

4. Write down any necessary information in the opening of the letter.

5. Write down specific information to indicate that your capability matches the position.

6. Write down any necessary information in the closing.

7. Sign your application letter.

The writing task above is writing short functional texts of an application letter. The writing materials can be controlled or guided writing. The task is guided writing because there

Chapter 5 (Who was Involved?)

Task 1, page 75. What is the Trending News? Write a piece of news item by responding to these questions.

1. What is the trending news you heard on TV or read in newspaper today?

2. What information can you collect? What are the details of information (who, where, what, why)?

are some guidelines provided and before writing they have to understand the text structure and language features of an application letter.

The writing task above is ordered the students to write short functional of the news texts. The writing material is guided writing because they are asked to write a news item by following the question provided. This activity involved them to understand the reported speech (direct speech and indirect speech) and the past verbs.

The writing task above is to write a summary of the news. Students must be able to

Chapter 6 (Online School Registration )

Task, page 91. Summarize the news. Cut any news from any newspaper and bring it to tho nlaco

Chapter 7 (It's Garbage In, Art Works Out?)

Task, page 107 . Let's do a role play. Role Play two - news writing and broadcast

1. Work in groups of four to five.

2. Look for interesting things in the class and school or around that are worth reporting. Your group may need to interview some people (witnesses) of the thing you want to report. Decide who will interview whom.

3. Work together to write and edit a news report based on the information you have collected. Study again the previous discussion on the grammar, expressions, and organization of ideas of news report.

4. Decide who will be the broadcaster in the studio, reporter(s) in the field, and actors and witnesses of the event told in the news report. The group can also designate some members to be the experts who give comments about the event. Try your best and enjoy the role-play.

5. Read again the instructional objectives. Is there any objective that you have not been able to accomplish? Read the activity which is still difficult. Don't hesitate to ask for help from your teacher. 
summarize the news from the newspapers.

The writing task above is writing short functional texts of news and role play. The writing material is guided writing because there are some guidelines provided. Students work in groups to write then edit the news report. The activity involved the students paying attention to the grammar, expressions, and organization of ideas of the news report. This task presents by a roleplaying which consists of a broadcaster, a reporter, an actor and the witnesses of the event told in the news report.

Chapter 8 (How to Make)

Task 3, page 116. Complete the description. Fill in the blanks with the appropriate words.

Crab soup might become one of the favorite foods for many families. These are the steps to make crab soup.

1. Place whole tomatoes, water, lima beans, corn, carrots, chopped onion, Old Bay seasoning, and beef broth, in a 4 quart cover, and for 5 minutes.

2. Bring water to Add crab claws and boil 6 minutes. Drain and set aside.

3. Stir crabmeat (and crabs claws, if desired) into tomato and vegetable Cover and simmer 10-15 minutes longer. hot.

The writing task above is completing sentences of the procedure text. The procedure text

Chapter 9 (Do it carefully!)

Task 5, page 132. Create your own text. Now, write a procedural text of your own. Choose a goal that you are good at. You can go to the library or search in the Internet to find help. Use these points when writing the text.

1. What is the goal?

2. What are the materials/things/ingredients needed?

3. What are the steps to do?

tells about the steps to make a crab soup. It is guided writing because before complete the blank words the students have to know the meaning of the sentences to choose the appropriate words to give instructions.

The writing task above is writing short functional texts of a procedure text. The writing material is guided writing because there are guidelines when writing and before writing, they

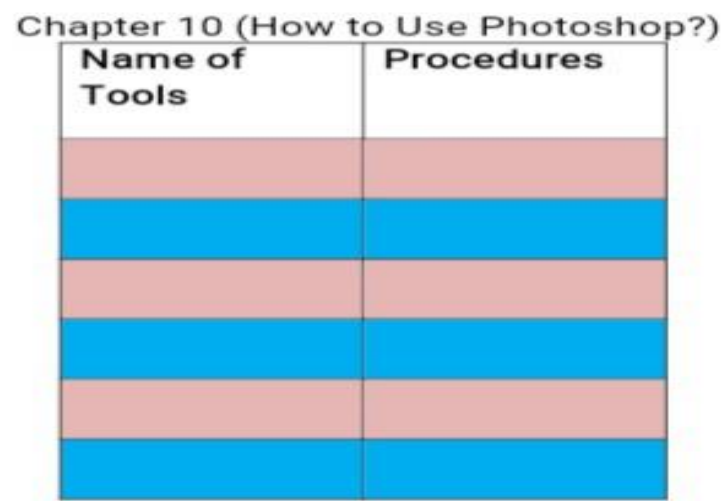

Task 2, page 146. Have conversation in pairs. Now, work in pairs! By using the table above, tell your friends what you should do to operate each tool. Give the instructions in turns. 
have to understand the text structure and language features of the procedure text.

The writing task above is writing short functional texts of operating the tools. It is guided writing because the first students are asked to fill in the name of tools and the procedures based on the table above, then they work in pairs to make a conversation to operate each tool based on the table above. This activity involved them choosing the appropriate phrase and sentence to give instructions.

The writing task above is ordered students to write sentences dealing with grammar. The activity involved them work two or three to answer and discuss based on the questions provided. Before answer the question they have to know the meaning of the song lyrics. This activity can improve their vocabulary and their ability to translate words.

\section{The relatedness between K13 curriculum and writing materials}

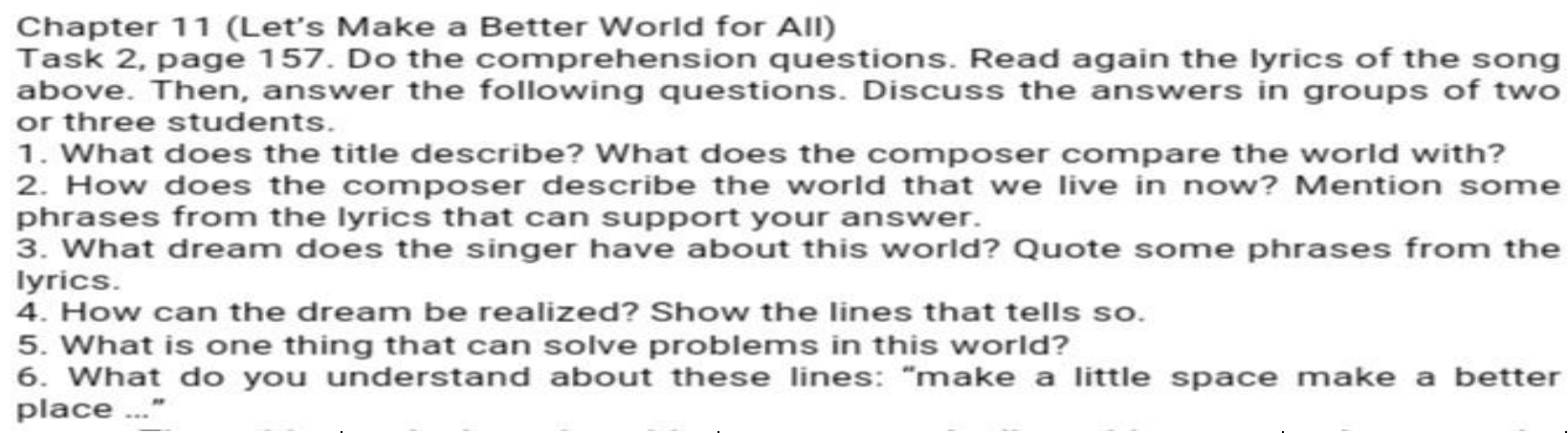

\begin{tabular}{|c|c|c|c|}
\hline $\begin{array}{l}\text { texts to offer } \\
\text { services and } \\
\text { responses }\end{array}$ & & do...? What if ...? & \\
\hline $\begin{array}{l}\text { Oral and written } \\
\text { texts to state and } \\
\text { ask questions } \\
\text { about } \\
\text { presuppositions } \\
\text { followed by } \\
\text { commands/suggest } \\
\text { ions }\end{array}$ & $\begin{array}{l}\text { Why Don't You } \\
\text { Visit Saeattle? }\end{array}$ & $\begin{array}{l}\text { Present Tense } \\
\text { - Conjunction: if, unless } \\
\text { - Imperative sentences: why } \\
\text { don't you... youshould, got... } \\
\text { - modals: need, should, have to } \\
\text { - vocabs: nouns and verbs } \\
\text { related to the topics }\end{array}$ & Not related \\
\hline
\end{tabular}




\begin{tabular}{|c|c|c|c|}
\hline Captioning text & Creating Captions & $\begin{array}{l}\text { - Word } \\
\text { - Phrase } \\
\text { - Clause } \\
\text { - Sentence }\end{array}$ & Related \\
\hline $\begin{array}{l}\text { Special texts, oral } \\
\text { and written, in the } \\
\text { form of a job } \\
\text { application letter }\end{array}$ & $\begin{array}{l}\text { Do You Know How } \\
\text { to Apply for a Job? }\end{array}$ & $\begin{array}{l}\text { - Vocabs, phrases, and sentences } \\
\text { used in a letter of application } \\
\text { - Active passive voices }\end{array}$ & Related \\
\hline \multirow{3}{*}{$\begin{array}{l}\text { Simple text news } \\
\text { from newspapers, } \\
\text { radio and TV }\end{array}$} & Who was Involved? & $\begin{array}{l}\text { - Topic related vocabulary } \\
\text { - Reported speech (indirect } \\
\text { speech) vs direct speech Topic } \\
\text { - Past verbs }\end{array}$ & Related \\
\hline & $\begin{array}{l}\text { Online School } \\
\text { Registration }\end{array}$ & $\begin{array}{l}\text { - Headlines } \\
\text { - Quotes } \\
\text { - Direct-indirect sentences } \\
\text { - Prepositions }\end{array}$ & Not related \\
\hline & $\begin{array}{l}\text { It's Garbage In, Art } \\
\text { Works Out }\end{array}$ & $\begin{array}{l}\text { - Headlines } \\
\text { - Quotes } \\
\text { - Direct-indirect sentences } \\
\text { - Prepositions }\end{array}$ & Related \\
\hline \multirow{3}{*}{$\begin{array}{l}\text { Oral and written } \\
\text { procedural texts in } \\
\text { the form of } \\
\text { prescriptions }\end{array}$} & How to Make & $\begin{array}{l}\text { - Phrase and sentences to give } \\
\text { instructions }\end{array}$ & Related \\
\hline & Do it Carefully! & $\begin{array}{l}\text { - Topic related vocabulary } \\
\text { - Commands (imperatives) } \\
\text { - Adverbial Phrase }\end{array}$ & Related \\
\hline & $\begin{array}{l}\text { How to Use } \\
\text { Photoshop? }\end{array}$ & $\begin{array}{l}\text { - Phrase and sentences to give } \\
\text { instructions }\end{array}$ & Related \\
\hline Songs & $\begin{array}{l}\text { Let's Make a Better } \\
\text { World for All }\end{array}$ & - Topic related vocabulary & Related \\
\hline
\end{tabular}

Table.1 The relatedness between K13 curriculum and writing materials 


\section{Discussion}

From the table 1 above, the researcher discussed each topic of writing material found in Bahasa Inggris textbook.

Chapter 1 "May I help You" is the first topic of the textbook. This topic tells about offering help to someone. This topic already has an example of offering help and response in dialogue. The writing material found in the speaking task, which task asked the students to write a dialogue of offering help based on the situation is given in the task. So the writing material in this topic is related to the 2013 curriculum.

Chapter 2 "Why Don't You Visit Seattle?" is the second topic of writing learning material. This topic is not related to the 2013 curriculum. At the start of the topic, there is an explanation and example of using if clause that can help students understand it easily. The writing material is to find the pattern of the if clause in the other text.

Chapter 3 "Creating Captions" is the third topic of writing material. This topic is related to the English 2013 curriculum. There is a short explanation about the meaning and the criteria for creating a good caption, so the students can understand easily to write a caption related to the picture. The writing material is about creating a caption from the picture.

Chapter 4 "Do You Know How to Apply for a Job?" is the fourth topic of writing learning material in the textbook. This topic is related to the 2013 English curriculum. There is an explanation about the parts of an application letter which that can help the student understand it easily. The writing material is ordered the students to respond to the job vacancy.

Chapter 5 "Who was Involved?" is the fifth topic of writing learning material in the textbook. This topic is related to the English syllabus of the 2013 curriculum because this topic has an explanation about a news item and text structure which can help the students give a response and create a news item from the newspaper/radio/tv. The writing material is about to write a news item. 
Chapter 6 "Online School Registration" is the sixth topic of writing learning material in the textbook. The writing material is not related to the 2013 curriculum, because the writing material summarizes the news.

Chapter 7 "It's Garbage In, Art Works Out?" is the seventh topic of writing learning material in the textbook. The writing material is related to the 2013 English curriculum. There is an example of news text from a newspaper. The writing material presents the news report by role play.

Chapter 8 "How to Make" is the eighth topic in the textbook. This topic learns about a procedure text. A procedure text aims to describe the sequence of activities or steps that have done in doing something. There is an example of procedure text that can help students understand it easily. The writing learning material is related to the 2013 English curriculum. In this chapter, the writing material is to complete the blanks words of the procedure text.

Chapter 9 "Do It Carefully!" is the ninth topic of writing learning material. This topic is the same as the topic in chapter 8 that explains the procedure text or how are the steps to do something. The writing material explains that in the procedure text contains a lot of commands (Imperative sentences) such as to get, prepare, etc and also explains time sequences such as first, second, third, etc. The writing learning material is related to the the 2013 curriculum. There is an explanation of using imperative sentence and time sequences that can help the students to write a procedure text.

Chapter 10 "How to Use Photoshop?" is the tenth topic of writing learning material. This topic is also the same as the topic in chapters 8 and 9 that discuss about procedure text. This topic explains that a procedure is a series of an action that we have to follow in dong something. The writing material is related to the 2013 curriculum. There is an explanation about the procedures and example by using commands (imperative sentences) and time sequences such as first, second, etc. The writing material asked students to write procedures about how is using a product. 
The last topic in Bahasa Inggris textbook is "Let's Make a Better World for All". This topic discusses a song. The writing learning material is related to the 2013 curriculum because the syllabus of the 2013 curriculum is also explained about a song. The writing material is to understand the meaning of the song lyric. 


\section{CHAPTER IV \\ CONCLUSION AND SUGGESTION}

\section{CONCLUSION}

1. There are 11 topics of writing material in Bahasa Inggris textbook. The topic of writing material explains asking and offering help, conditional sentence, creating caption, application letter, news item, procedure text, and song. There are some of the similarity topics which discuss news item, namely in chapter 5, 6 and 7. Besides, chapters 8, 9 and 10 are the same topics too which discuss a procedure text.

2. The writing material was written as writing tasks. The writing tasks form as completing the text, writing sentences which dealing with grammar and writing short functional text. The tasks are given in the textbook can increase student's writing skills because before writing the task there is an explanation and example that can help students understand the writing material. Bahasa Inggris textbook has the information of vocabulary builder that can develop students' vocabulary in writing. only chapter 3 does not give the information of vocabulary in the textbook. Vocabulary is important because it can increase students' knowledge of vocabulary when writing, so it can help them to express their ideas. And the vocabulary section is line with the writing material. On the other hand, the textbook gave the task of grammar review directly on some chapters. We found in chapter 1 the task of grammar review about the pattern of expressions and response of offering help/services. Chapter 2 is about the pattern of the if clause. Chapter 4 is about active and passive voice. Chapter 5 is about direct and indirect speech. Chapter 6 is about direct and indirect sentences that appear in the news headline. Chapter 7 is about adding the suffix -ion to be a verb. Chapter 9 is about the use of commands ( imperative) and adverbials. There are some chapters do not cover the task of grammar review, such as in chapter 3, 8, 10 and 11. Though the information of vocabulary and the grammar review become the essential factors to form the students capable in writing.

3. The writing materials of the textbook have been related to the 2013 English curriculum, becaue the $\mathrm{KD}$ and the indicators have been implemented and appropriate based on the English 2013 curriculum. It is proven by the content of the material on the syllabus of the 2013 English curriculum. Some chapters are not related to the English syllabus of the 2013 curriculum. They are in chapters 2 and 6. 


\section{SUGGESTION}

Eventhough the writing materials offered in the textbook "Bahasa Inggris textbook:" for 12th grade of students Senior High School has related and implemented based on the 2013 curriculum, the researchers still have suggestions as follow:

1. For the teachers

the teacher should develop the grammar used in writing material because the grammar found in the textbook is limit to explanation. Besides, the teacher should provide the vocabulary knowledge in case to increase their vocabulary when writing, so it can help students make up sentences.

2. For the readers

The researchers invite the readers to find out how important and relatedness between the writing materials in the textbook to the 2013 curriculum.

3. For the further research.

By conducting a research on writing material, hopefully, can increase the knowledge and qualities of learning English language. 


\section{REFERENCES}

Anderson, B. (2007). Pedagogical Rules and Their Relationship to Frequency in Input. Observational and Empirical Data fromFrench: Applied Linguistics 28 (2), available online at:citeseerx.ist.psu.edu/viewdoc/download?doi=10.1.1.130.8533\&rep=rep1\&typepdf. on 19/06/2017.

Graves, C. (2000). Designing Language Course a Guide for Teacher. Canada: Heinle.

Hutchinson, Water and Allan Waters. (1987). English for Specific Purpose. Cambridge: Cambridge University Press.

Langan, J. (2001). English Skill. New York: Mc Graw-Hill Companies, Inc.

Mulyasa, H. E. (2013). Pengembangan dan Implementasi Kurikulum 2013. Bandung: PT Remaja Rosdakarya.

Rully Indrawan and Poppy Yaniawati. (2014). Metodologi Penelitian (Kuantitative, Kualitativ, dan Campuran untuk Manajemen, Pembangunan dan Pendidikan. Bandung: PT Refika Aditama.

Sholichatun, S. F. (2011). Content Analysis of Reading Materials In English On Sky Textbook For Junior High School. Semarang: Walisongo State Institute For Islamic Studies.

Stemler, S. (2001). An overview of content analysis.Practical Assessment. Research \& Evaluation. Yale University.

Sugiyono. (2010). Metode Penelitian Pendidikan. Cetakan Kedua belas, Bandung: Alfabeta.

Tomlinson, B. (1998). Materials Development in Language Teaching. Cambridge: Cambridge University Press.

Van Dormolen, J. (1986). Textual analysis. Dalam B. Christiansen, A. G. Howson, \& M. Otte, Perspectives on mathematics education (hal. 141-171). Dordrecht: D. Reidel Publishing Company. 